\title{
Preliminary Study on HFSE Mineralization in the Peralkaline Granites of Nusab El Balgum Area, South Western Desert, Egypt
}

\author{
S. A. Abu Elatta, H. M. Assran, A. A. Ahmed \\ Nuclear Materials Authority, Cairo, Egypt \\ Email: dr.soliman72@yahoo.com
}

Received February 7, 2013; revised March 7, 2013; accepted March 15, 2013

Copyright (C) 2013 S. A. Abu Elatta et al. This is an open access article distributed under the Creative Commons Attribution License, which permits unrestricted use, distribution, and reproduction in any medium, provided the original work is properly cited.

\begin{abstract}
Nusab El Balgum mass complex represents one of peralkaline volcanic activity phenomena in the south Western Desert of Egypt, which is typical for within-plate event, which formed in Mesozoic period. It consist of acidic volcanic (rhyolite and their pyroclastics) and sub-volcanic granitic rocks (incomplete ring, small stock and dyke of a peralkaline aphanites) as well as dykes (trachyte, bostonite, rhyodacite, rhyolite and porphyritic rhyolite) variable in thickness and the most of run in NNE-SSW trend. The peralkaline granitic rocks, especially that located at the southwestern part of this mass is characterized by extreme enrichments in HFSE (rare metals such as $\mathrm{Zr}, \mathrm{Nb}, \mathrm{U}$ and Th and REEs). The highest concentrations (e.g., $>1 \% \mathrm{Zr}, 0.5 \% \mathrm{Nb}$ and $2.6 \%$ total REEs, $\mathrm{Y}$ up to $1 \%$, eU up to $300 \mathrm{ppm}$ and eTh up to $1100 \mathrm{ppm}$ ). The rare metal bearing minerals are thorite, uranothorite, autunite, amorphous secondary uranium, zircon and ferrocolumbite, while the REEs bearing minerals are bastnaesite, monazite and xenotime. The positive relations in all of the binary diagrams of $\mathrm{Zr}$ versus $\mathrm{Nb}, \mathrm{Y}, \mathrm{eU}$ and $\mathrm{eTh}, \mathrm{Nb}$ versus $\mathrm{Y}, \mathrm{eU}$ and $\mathrm{eTh}, \mathrm{Y}$ versus eU and $\mathrm{eTh}$ in post magmatic intensely hematised peralkaline granites indicated that, this process is responsible for the enrichment in these HFSE. The chondrite-normalized pattern of high-altered peralkaline granites indicates: 1) higher LREEs enriched pattern $(\mathrm{La} / \mathrm{Gd}=$ 11.34 and 12.25) means the alteration processes took place under open system and these rocks evolved from magma of lithospheric rifting, 2) $\Delta \mathrm{Ce}<1$ anomaly, means that the alteration fluids were slightly oxic and 3) strong negative$\Delta \mathrm{Eu}<1$. This indicates the nature of residual peralkaline melt: a) it was extremely rich in fluorine, $\mathrm{H}_{2} \mathrm{O}$, and thus very low viscosity, despite its low temperature $\left(<650^{\circ} \mathrm{C}\right)$; b) it was strong depleted in feldspar-compatible elements, as indicated by strong negative Eu anomalies; and c) it had abundances of HFSE cations. Redistribution of elements took place by post magmatic hydrothermal solutions.
\end{abstract}

Keywords: Peralkaline Granites; Thorite; Amorphous Secondary Uranium; Compatible Elements; Lithospheric Rifting

\section{Introduction}

The peralkaline granitic rocks were emplaced as dykes and small stocks, characterized by economical to subeconomical deposits of high-field strength elements (HFSE, i.e., REE, Zr, Y, Nb, etc.) as stated by [1,2]. Due to a recent increase in the demand for these metals, these rocks have become the focus of extensive exploration. There is no consensus on the mode of formation of this type of mineralization, and a particularly debated topic is whether HFSE deposits are solely products of primary enrichment or whether hydrothermal processes can favor economic concentrations (e.g. [3], for a review). In the end of last century, the solubility experiments have established that the low degree of polymineralization in peralkaline melt stabilizes the HFSE in melts (e.g. [4,5]). Many authors (e.g. [6]) attributed the high concentrations HFSE in peralkaline granites to characteristics of peralkaline melts, which allow them to accommodate higher proportions of these elements than other melts. The association of extreme HFSE with the hydrothermal alteration processes as in case peralkaline granite of Lake Strange and other plutons, suggests these processes may play a role in HFSE concentrations [7]. The extreme enrichment of HFSE in The Lake Strange found in intensity-hematised zone and concentrated by hydrothermal alterations [8].

In this paper, the analyzed HFSE (REEs by ICP and rare metals by XRF) results from Nusab El Balgum altered peralkaline granites of anorogenic peralkaline 
aphanity, provide direct evidence for extreme enrichments of HFSE and volatiles $\left(\mathrm{CO}_{2}, \mathrm{~F}\right.$ and $\left.\mathrm{H}_{2} \mathrm{O}\right)$. The comparison between slightly altered granite and highaltered one occur in the study area, indicate the role of post magmatic hydrothermal alterations in redistributions and the concentrations of HFSE in these rocks. While the Chondrite-normalized REEs pattern indicate physio-chemical conditions, which are prevailing during alterations processes.

\section{Geology and Petrography}

Nusab El Balgum mass located in the south Western Desert of Egypt, to North of Bir Safsaf Precambrian basement rocks, along intersection of longitude $29^{\circ} 18^{\prime}$ and latitude $23^{\circ} 17^{\prime}$ (Figure 1). The study area can be reached through asphaltic road from Aswan-Tushki (220 Km)Darb El Arbain $(226 \mathrm{Km})$-El Kharga road north $(90 \mathrm{Km})$ Bir Abu El Hussien-Bir Tarafawi west $(80 \mathrm{Km})$ along old asphaltic road. Also can be reached through El DakhlaSharq El Uweinat village and to the east $(50 \mathrm{Km})$ through Bir Tarafawi-Bir Abu El Hussien old asphaltic road, and finally taking the north direction cross desert track for $40 \mathrm{Km}$.

The alkaline magmatic activity in south of Egypt (including Nusab El Balgum) can be related to major tectonic event [9-11]. Black et al. [12] and Bowden [13] also reported that, the occurrence of alkaline provinces in North Africa (including Egypt) are controlled by major lithosphere weaknesses represented by the above TAL (Trans African Lineament) and CAL (Central African Lineament) megashears (Figure 2). It is clear that, the
ENE-WSW trending tectonic zones in southern Egypt have a comparable strike of these two major megashear zones [14].

Nusab El Balgum mass complex occurs as elongated body $\left(12 \times 3.5 \mathrm{Km}^{2}\right)$ trending in NNE-SSW direction and surrounded by the peneplained surface of older sandstones of Six Hills Formation (the age of this Formation is late Jurassic-early Cretaceous [15] and windblown

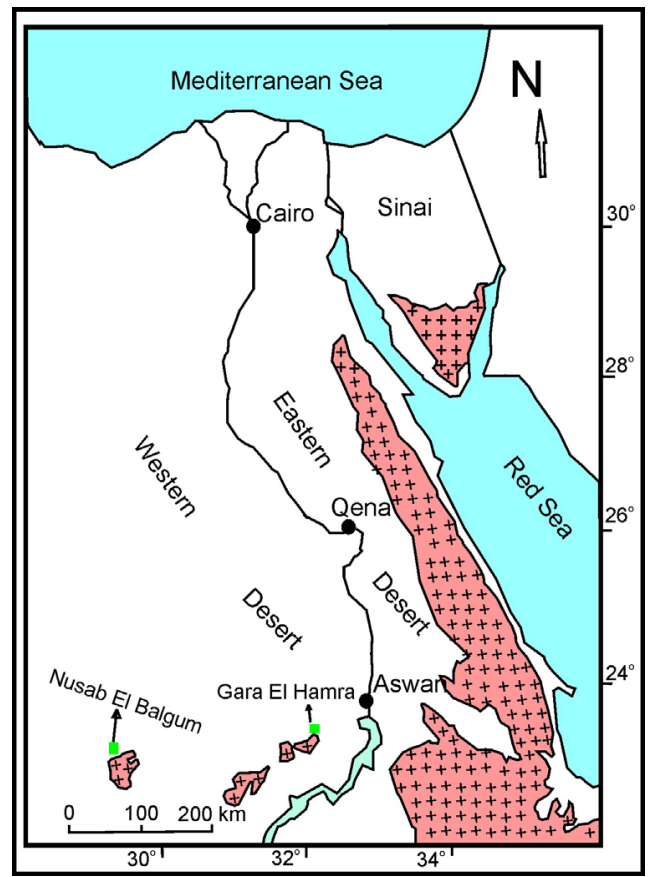

Figure 1. Location map of the study area.
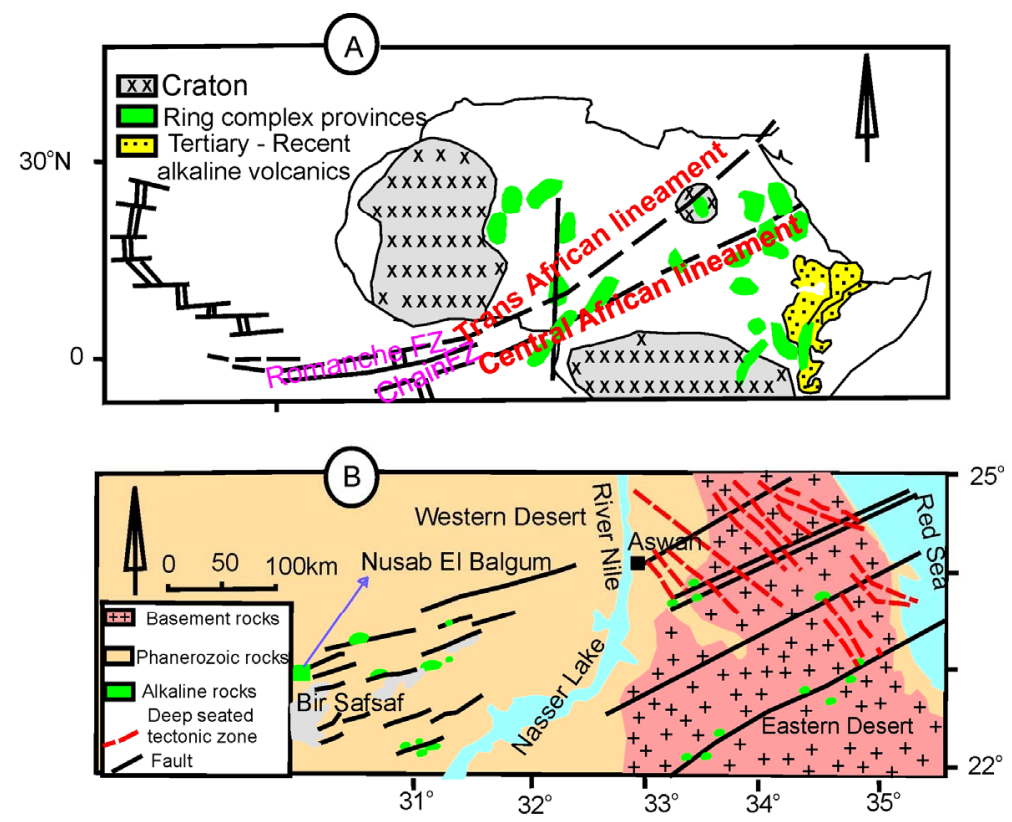

Figure 2. (A) Precambrian cratons, alkaline provinces and Trans African Lineament (TAL) and Central African Lineament (CAL) of the Northern Africa; (B) Lineament map and alkaline complex of the southern Egypt and Nusab El Balgum alkaline mass. 
recent sands (Plate 1(a)). The main mass complex of Nusab El Balgum is composed mainly of rhyolitic lava flow, banded tuffs, agglomerates, jasperoid veinlets or clots, breccia of vent type (Plates 1(b) and (e)). The rest of this mass is represented sub-volcanic granitic intrusions as well as many volcanic dykes (trachyte, bostonite, rhyodacite, rhyolite and porphyritic rhyolite). So that, Nusab El Balgum mass complex can be considered or represent a caldera complex, where a caldera as large basin-shaped volcanic depression with diameter greater many times than that of the included vent or vents. Cal- dera complex comprises dykes, sills, stocks, vent breccias, talus beds of tuffs and agglomerates beside the crater or main mass filled with lava.

Nusab El Balgum mass complex, may be due to the intersection of an ENE-WSW trend of CAL (the most important part of this lineament in the southwest of Egypt is the Kalabsha fault [16], with Tarafawi-QenaSouth Sinai Arch of NE trend (Arch, built along major fracture zone forming the plate or sub-plate). This volcanicity took place in Permo-Triassic age according to [17] but from geologic evidence, these volcanic may be

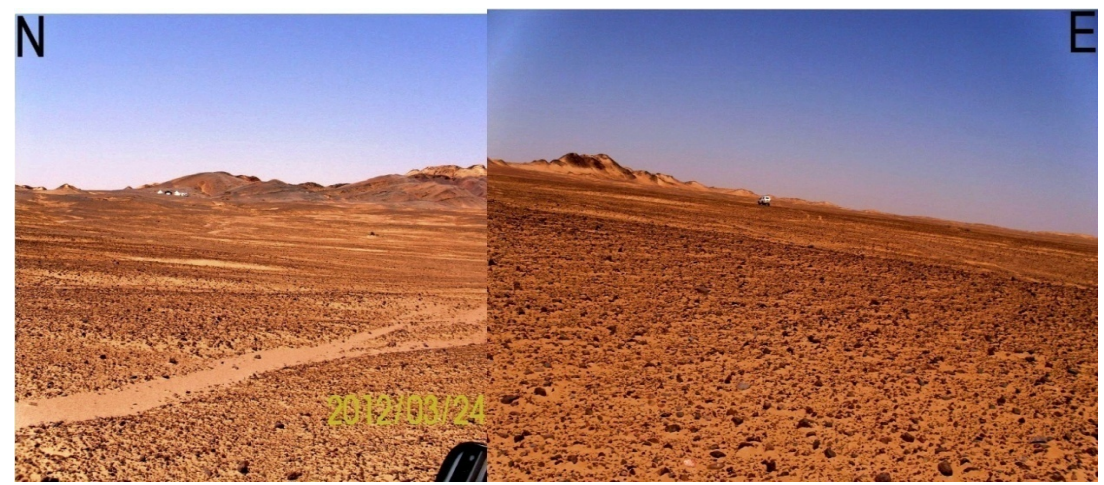

(a)

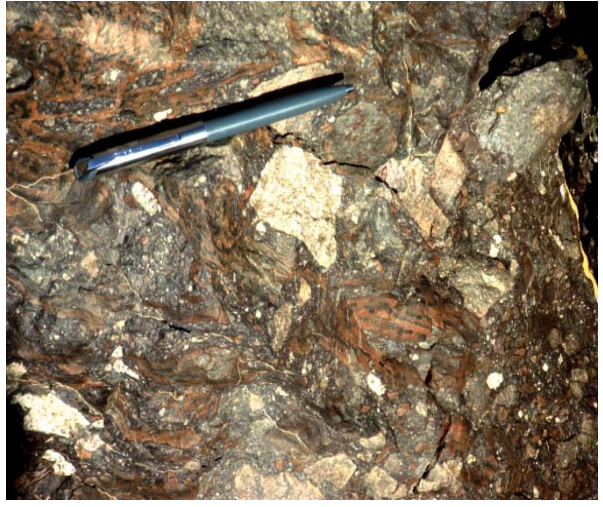

(b)

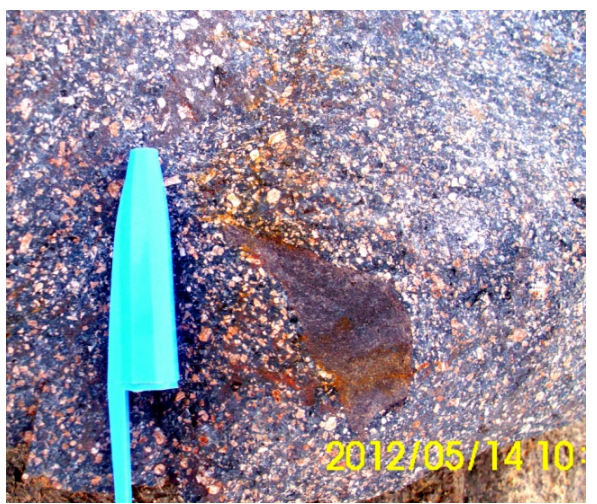

(d)

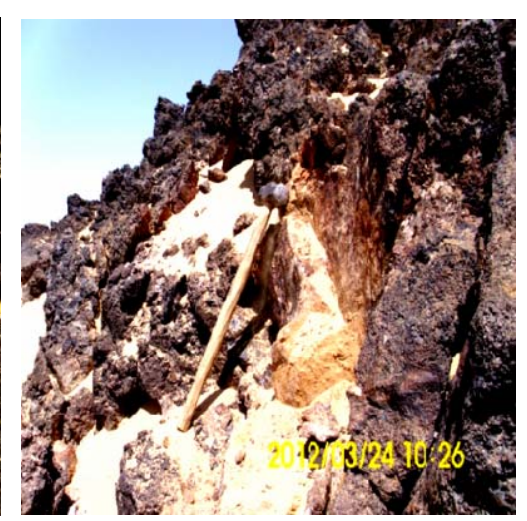

(c)

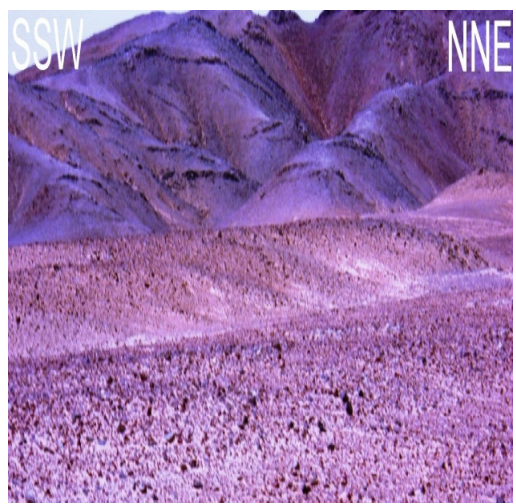

(e)

Plate 1. View showing: (a) Nusab El Balgum mass complex extends in NNE-SSW; (b) Vent breccias type; (c) Close up view of Nusab El Balgum altered peralkaline granites; (d) Xenolith of volcanic within altered peralkaline granites; (e) Dykes (trachyte and rhyolite) run in the NNE-SSW direction and cut pyroclastic rocks. 
begin at Late Jurassic age associated with rifting central and South Atlantic Ocean which led to the formation of main mass. The Nusab El Balgum peralkline granites (Plate 1(c)) emplaced during late Cretaceous or after that, where many xenoliths from both of volcanics (Plate 1(d)) and sandstones of Six Hills Formation found within their shield margins. These granites formed because of the continue reactivations the faults and the reduce pressure in the volcanic chamber after the extrusion of lava led to the tremendous weight of core rocks. The final stage of Nusab El Balgum represented by the dykes cut all the rocks of Nusab El Balgum mass. These dykes are different directions but the most of them were running in NNE-SSE directions (Plate 1(e)). In addition, they differ in width and length.

According to above results, the different rock varieties that cropping out at Nusab El Balgum area can be arranged from youngest to oldest as follow (Figure 3):

- Sand dunes and sand sheets;

- Dykes;

- Altered peralkaline granitic rocks;

- Altered peralkaline volcanic rocks and their pyroclastics;

- Sandstones of Six Hills Formation.

Altered peralkline granites occur as incomplete ring and stock-like intrusions as well as small dyke running

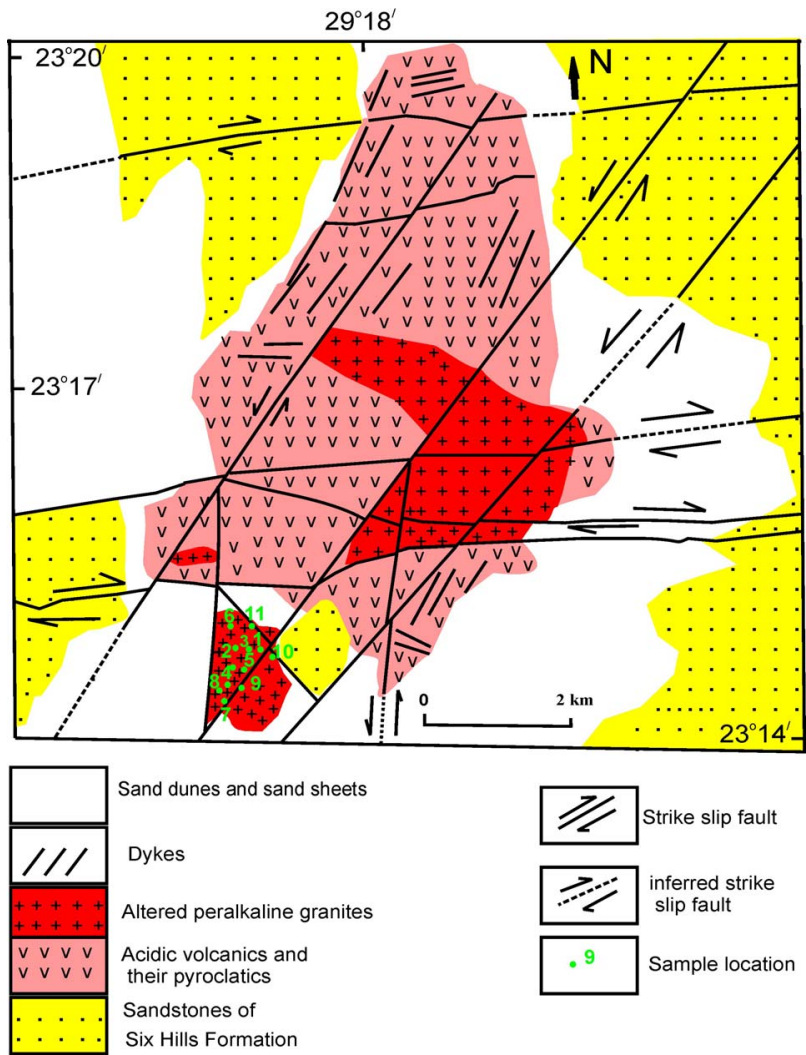

Figure 3. Geologic map of the study area and the dominant structure trends.
ENE-WSW (Figure 3). The two later forms are higher in HFSE. Peralkaline granites undergo hydrothermal alterations (e.g. Silicification, Fe-Mn oxy-hydroxides, Sericitization, Carbonatization and Kaolinitization). According to the degree of hydrothermal alterations, the stocklike intrusion of altered peralkline granite divided to 1) slightly altered and 2) highly altered granites. The slightly altered one occurs, as rock fragments distributed on the top of this mass (may be represent the apical part of the origin granite before post magmatic alterations took place). The difference between two types of altered peralkaline granites is the occurrence fresh relic of alkali pyroxene and amphibole in slightly altered one as well as low intensity of iron oxides alterations.

The highly altered one is medium to coarse-grained and is dark color due to staining by Fe-Mn oxy-hydroxides, under microscope is mostly brecciated or silicified and generally is composed mainly of potash feldspars, quartz, altered alkali minerals, zircon, monazite and opaques. Potash feldspars occur as anhedral crystals of perthite (string and patch types) associating with quartz. Commonly potash feldspar crystals are intergrowth with quartz forming graphic texture. In the brecciate variety; quartz and potash feldspars are angular crystals surrounded by amorphous silica formed by action of the faults. In the silicified variety; potash feldspar (perthite) is corroded by silica or completely transformed to silica due to hydrothermal solutions (Plate 2(a)). So that this type of granite is considered as a good target for radioactivity where the secondary radioactive minerals are formed by the hydrothermal process as amorphous uranophane associating the silicification (Plate 2(b)) or epigenetically filling the fractures in the primary quartz (Plate 2(c)). Autunite is another secondary radioactive mineral formed as rose-like crystals associating hematite upon the primary quartz (Plate 2(d)). Alkali minerals are completely metasomatized forming pseudomorphs of iron oxides and silica (Plates 2(e) and (f)) or altered to carbonate (Plate 2(g)). Both type of zircon occur, primary and secondary but the secondary one is the dominant one and occurring in clusters of short prismatic crystals (Plate 2(h)). Monazite occurs as minute crystals. Opaques occur as subhedral to anhedral crystals and the most of them are associated with pseudomorphs of alkali minerals.

\section{HFSE Concentrations}

\subsection{Analytic Techniques}

Eleven trace elements; were quantitatively determined for this study using XRF technique using Philips PW 1404 spectrometer of the wave length type for which powder pellets and fusion beads were prepared in laboratories of Nuclear Materials Authority of Egypt. The 


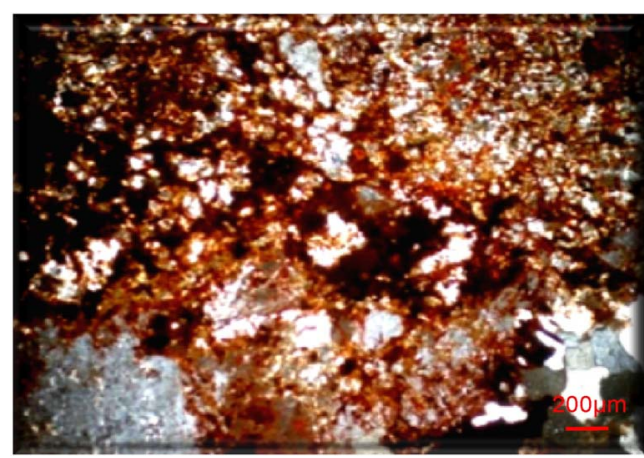

(a)

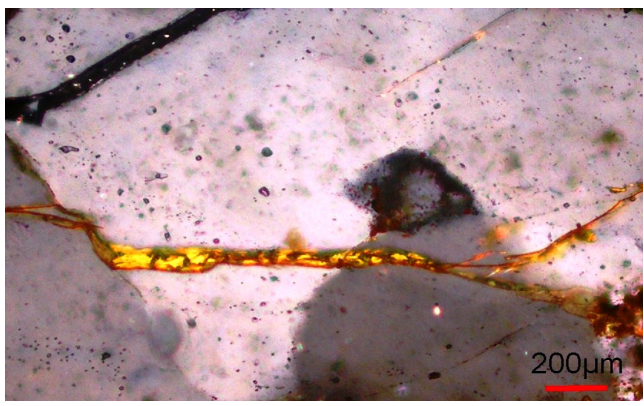

(c)

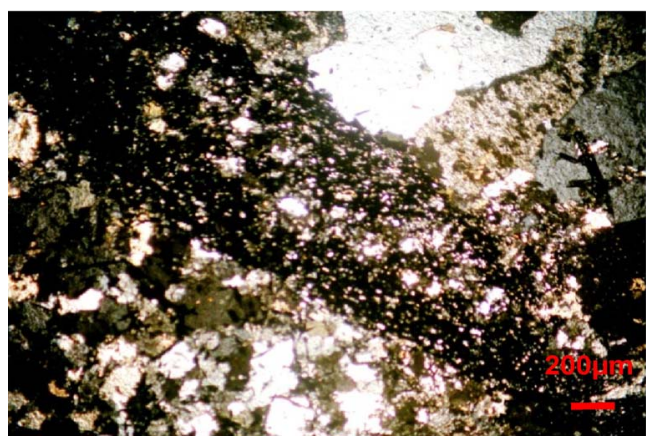

(e)

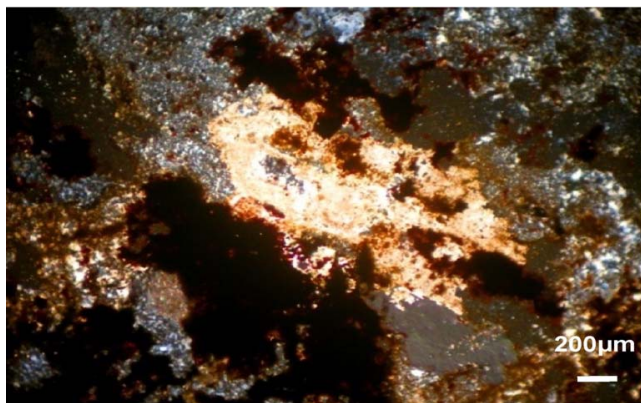

(g)

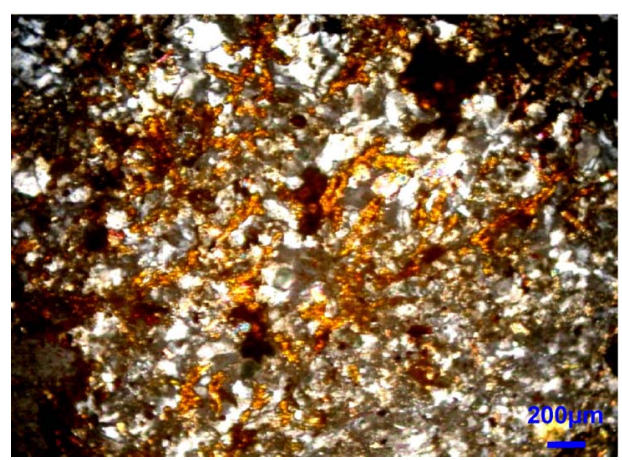

(b)

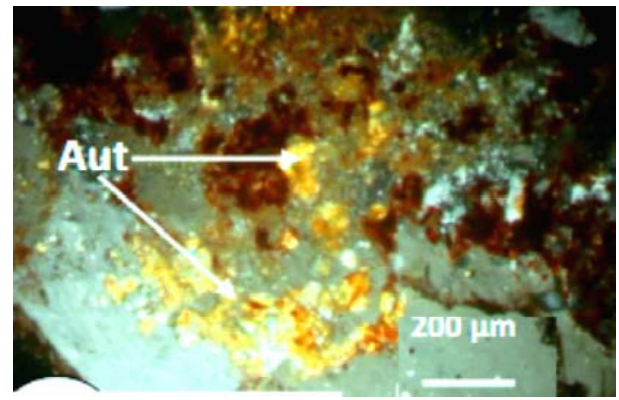

(d)

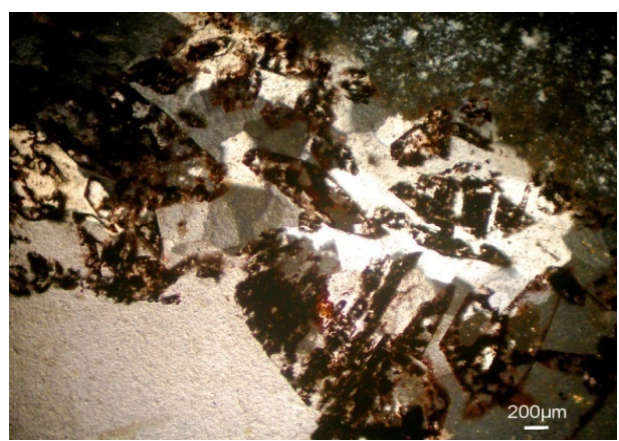

(f)

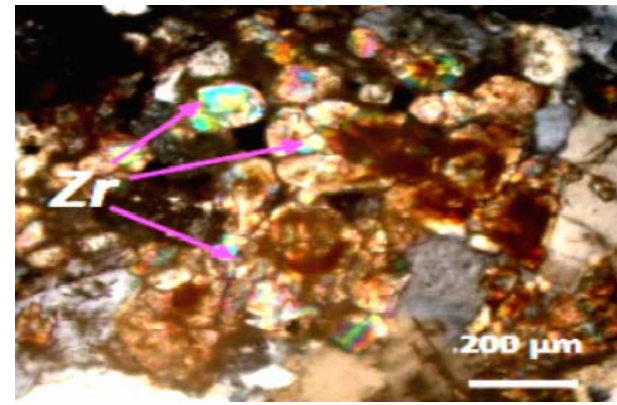

(h)

Plate 2. Photomicrographs showing: (a) Himatitised peralkaline granites by the action of post magmatic hydrothermal solutions; (b) An amorphous radioactive mineral associating silicification; (c) Fractures in quartz were filled by amorphous radioactive material; (d) Rose-shape crystals of autunite upon quartz crystal; (e) The pseudomorphs of alkali minerals (opaques and quartz); (f) The pseudomorphs of the alkali minerals transformed to iron oxides; (g) Alkali mineral wholly transformed to carbonate; (h) The clusters of the secondary zircon crystals.

radiometry measured by RS-230. The obtained data is present in (Table 1). In addition, two samples (9 \&10) were determined for REEs in management of chemical warfare in Egypt by using Agilent technologies 7700 series ICP-MS made in Japan. The obtained data is present in (Table 2). 
Table 1. Concentrations of some rare metals (ppm) of Nusab El Balgum altered peralkaline granites.

\begin{tabular}{|c|c|c|c|c|c|c|c|}
\hline S.N./element & $\mathrm{Zr}$ & $\mathrm{Y}$ & $\mathrm{Nb}$ & $\mathrm{eU}$ & $\mathrm{eTh}$ & $\mathrm{eTh} / \mathrm{eU}$ & Rock type \\
\hline 2 & 2104 & 935 & 404 & 13 & 26 & 2 & \multirow{4}{*}{ Slightly altered peralkaline granite } \\
\hline 4 & 2442 & 1088 & 480 & 30 & 81 & 2.7 & \\
\hline 6 & 1078 & 484 & 207 & 16 & 24 & 1.5 & \\
\hline 8 & 2652 & 1188 & 512 & 20 & 44 & 2.2 & \\
\hline 1 & $>10,000$ & 5262 & 2299 & 57 & 143 & 2.5 & \multirow{7}{*}{ Highly altered peralkaline granite } \\
\hline 3 & 4298 & 1912 & 828 & 38 & 86 & 2.2 & \\
\hline 5 & $>10,000$ & 4925 & 2139 & 155 & 453 & 2.9 & \\
\hline 7 & 8101 & 3591 & 1561 & 26 & 37 & 1.4 & \\
\hline 9 & $>10,000$ & 8216 & 3578 & 298 & 1107 & 3.7 & \\
\hline 10 & $>10,000$ & 9186 & 4041 & 92 & 319 & 3.4 & \\
\hline 11 & $>10,000$ & 4427 & 1921 & 54 & 154 & 2.8 & \\
\hline
\end{tabular}

Table 2. Concentrations of REEs (ppm) and their ratios in altered peralkaline granite as well as crustal abundance.

\begin{tabular}{|c|c|c|c|}
\hline & Sample 9 & Sample 10 & ${ }^{*}$ Crustal abundance \\
\hline $\mathrm{La}$ & 7940 & 3670 & 30 \\
\hline $\mathrm{Ce}$ & 12,600 & 7170 & 64 \\
\hline $\operatorname{Pr}$ & 1290 & 780 & 7.1 \\
\hline $\mathrm{Nd}$ & 4820 & 3050 & 26 \\
\hline $\mathrm{Sm}$ & 770 & 590 & 35 \\
\hline $\mathrm{Eu}$ & 46 & 32 & 0.88 \\
\hline Gd & 700 & 520 & 3.8 \\
\hline $\mathrm{Tb}$ & 103 & 80 & 0.64 \\
\hline Dy & 550 & 420 & 3.5 \\
\hline Ho & 110 & 87 & 0.8 \\
\hline $\mathrm{Er}$ & 310 & 240 & 2.3 \\
\hline $\mathrm{Tm}$ & 48 & 36 & 0.33 \\
\hline $\mathrm{Yb}$ & 280 & 203 & 2.2 \\
\hline $\mathrm{Lu}$ & 39 & 33 & 0.32 \\
\hline $\mathrm{La}^{*}$ & 33502.11 & 15485.23 & \\
\hline $\mathrm{Ce}^{*}$ & 20588.26 & 11715.69 & \\
\hline $\operatorname{Pr}^{*}$ & 13578.95 & 8210.53 & \\
\hline $\mathrm{Sm}^{*}$ & 5032.68 & 3856.21 & \\
\hline $\mathrm{Eu}^{*}$ & 793.1 & 551.72 & \\
\hline $\mathrm{Gd}^{*}$ & 3406.33 & 2530.41 & \\
\hline $\begin{aligned} \Delta \mathrm{Ce} & =2 \mathrm{Ce}^{*} / \mathrm{La}^{*} \\
& +\mathrm{Pr}^{*}\end{aligned}$ & 0.89 & 0.98 & \\
\hline $\begin{aligned} \Delta \mathrm{Eu} & =2 \mathrm{Eu}^{*} / \mathrm{Gd}^{*} \\
& +\mathrm{Sm}^{*}\end{aligned}$ & 0.19 & 0.17 & \\
\hline $\mathrm{La} / \mathrm{Gd}$ & 11.34 & 12.25 & \\
\hline
\end{tabular}

$\mathrm{La}^{*}=\mathrm{La}$ in sample/La in chondrite, ${ }^{*}$ Crustal abundance $=$ Taylor and McClennan [18].

\subsection{Minerals}

In general some rare elements (e.g. Zr, $\mathrm{Ta}, \mathrm{Nb}, \mathrm{Th}$ and $\mathrm{U}$ ) are been excluded from the structure of rock forming minerals of the granitic rocks during the crystallizations of the granitic magma and are progressively enriched in the residual melt until forming their own minerals in highly evolved magmas or during a pegmatitic stage. The accumulations these minerals at the top of the intrusive body remain in a cap on the top of pluton. In addition, these elements excluded from the structure forming minerals of peralkaline rocks during hydrothermal alterations and deposited in 1) apical part altered peralkaline rocks, 2) as veins or dykes and 3) sheet-like dykes that appear to be fracture or fault controls.

\subsubsection{Zirconium}

Zirconium occurs in magmas as a complex ion and fits with difficult into the common rock forming minerals because valency problems. Zirconium increases in later differentiates. In peralkaline rocks, alkali amphiboles and pyroxenes are the possible carriers of zirconium with not crystallized wholly as zircon minerals but will be mainly incorporate in the structure of these mafic alkali minerals [19]. So that, zircon is enrichment in alkaline rocks compared to calc-alkaline ones [20].

Taylor [21] had quoted Ringwood [22] finding that the high content of volatiles in alkaline magmas leads to a decrease in polymerization of the magmas and subsequent concentration of elements such as $(\mathrm{Zr}, \mathrm{Nb}, \mathrm{Ta}$, rare earth and forming elements of high ionic potential). According above result, the peralkline rocks show $\mathrm{Zr}$ abnormal concentration, where these rocks contain fluorite.

$\mathrm{Zr}$ concentrations in Nusab El Balgum slightly altered peralkaline granite ranges from 1078 to $2652 \mathrm{ppm}$ but in highly altered one, the most of them are more than 10,000 
ppm (Table 1). Zircon mineral in these study area occurs as simple prismatic crystals or aggregates, some of them are metamict (Plate 2(h)). There is a positive relation

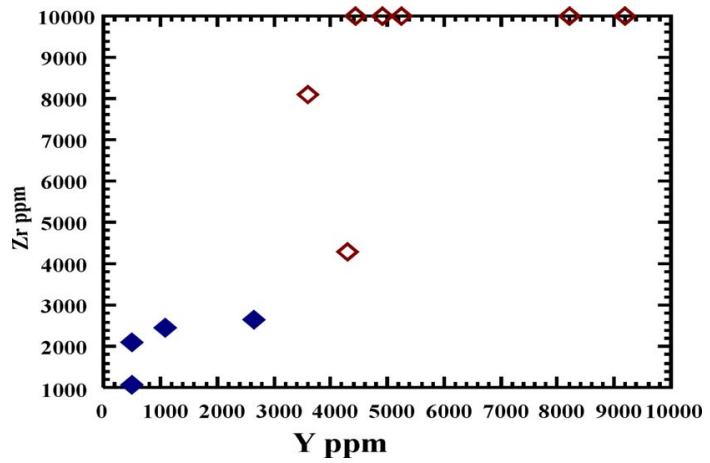

(a)

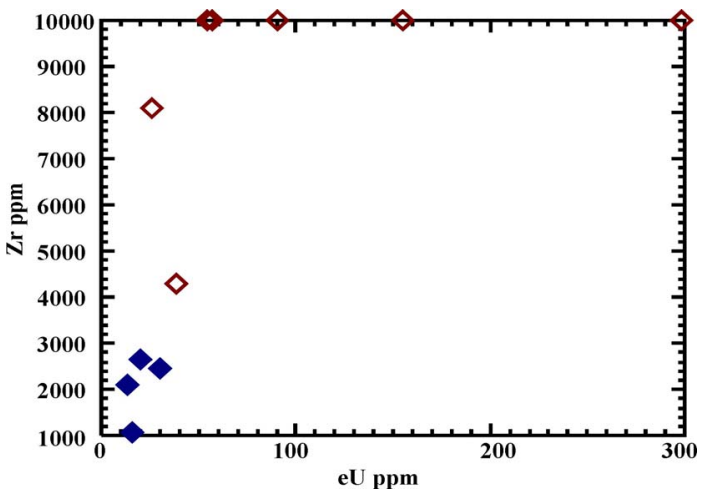

(c)

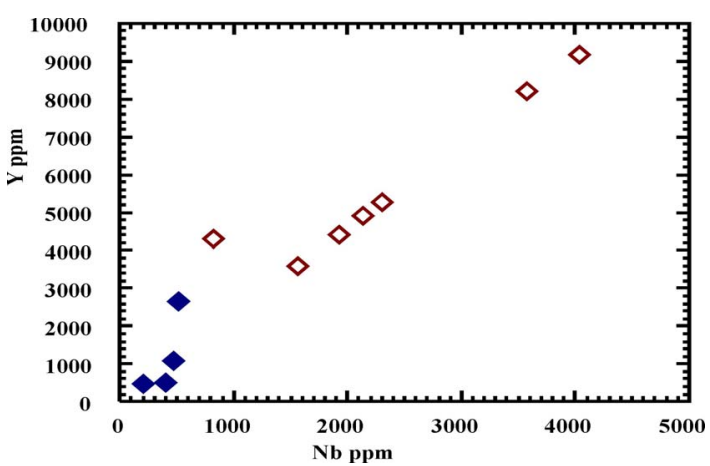

(e)

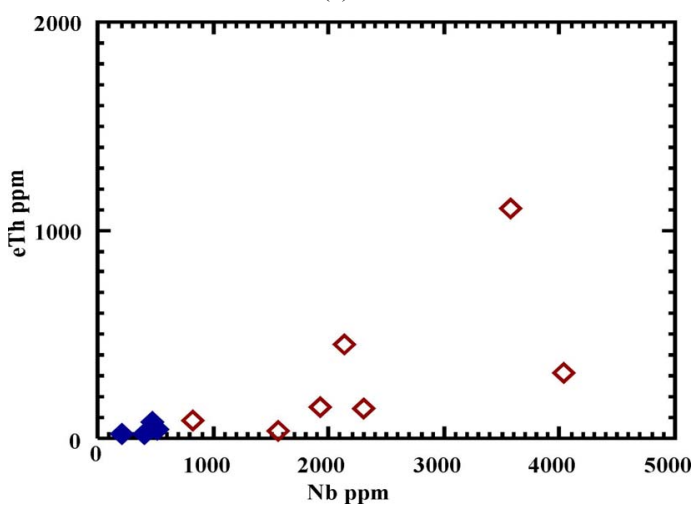

(g) between $\mathrm{Zr}$ and $\mathrm{Y}$ (a representative of REEs), $\mathrm{Nb}$, eU and eTh (Figures 4(a)-(d)) in the slightly altered peralkaline granite due to as mentioned above the both of

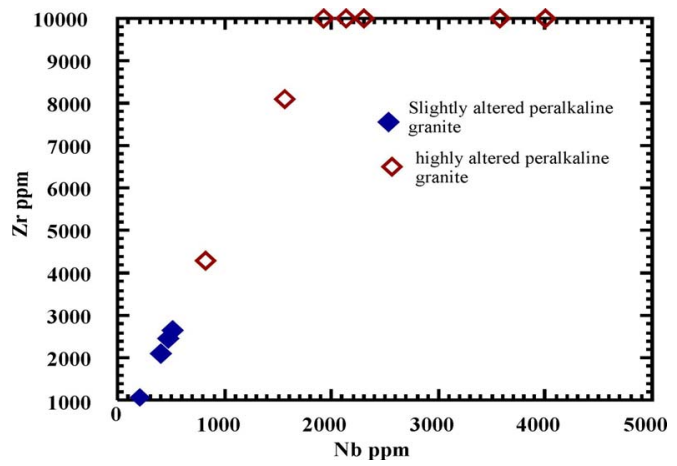

(b)

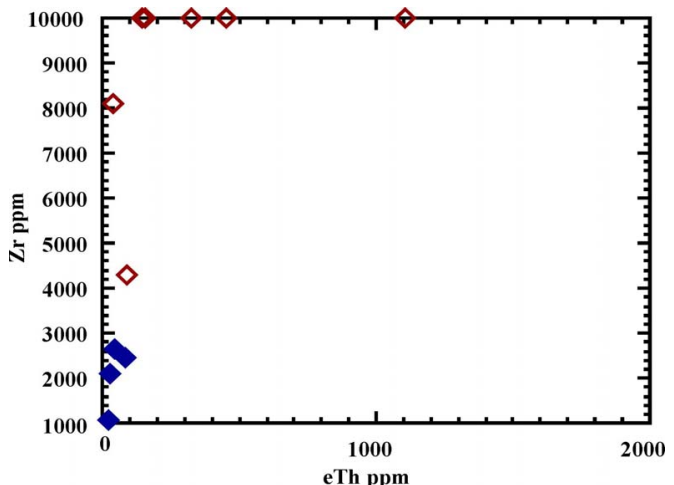

(d)

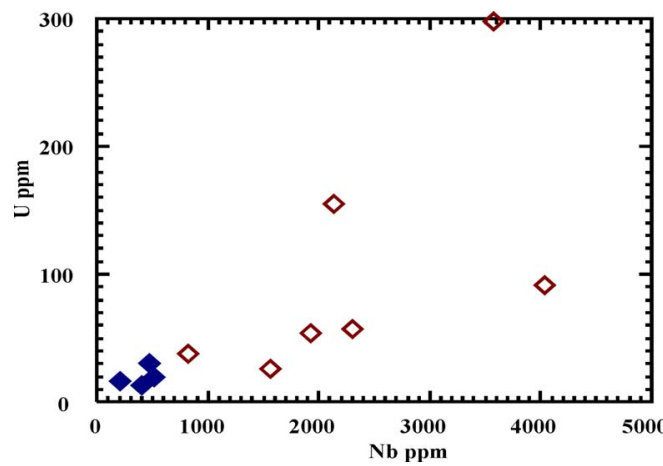

(f)

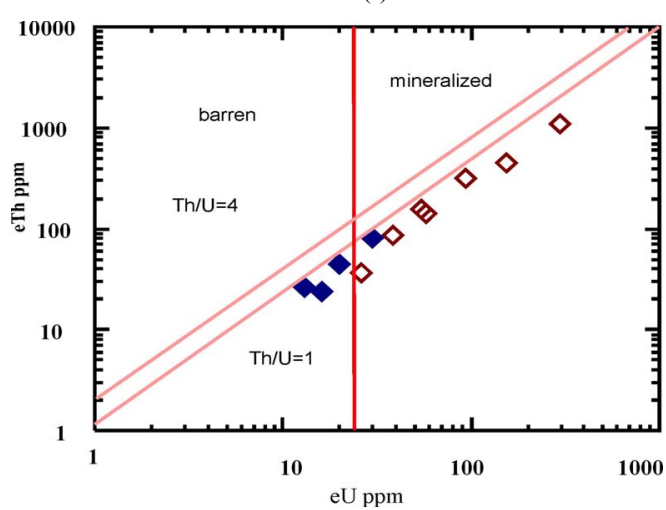

(h) 


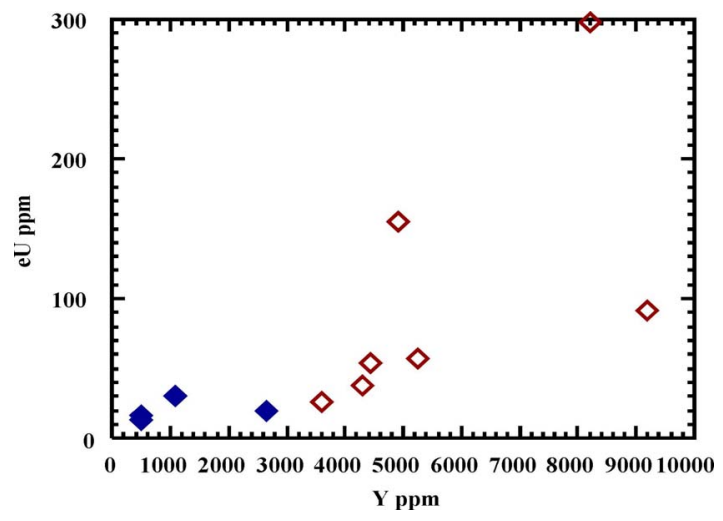

(i)

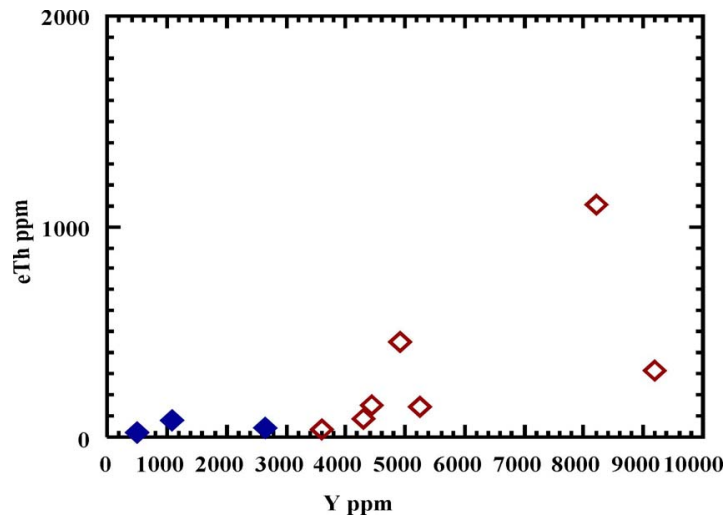

(j)

Figure 4. Binary show: (a)-(d) Zr versus $\mathrm{Y}, \mathrm{Nb}$, eU and eTh; (e)-(g) Nb versus $\mathrm{Y}$, eU \& eTh; (h) and (i) eU versus eTh (the mineralized and barren fields [24] \& Y; (j) eTh versus $Y$.

$\mathrm{Zr}$ and $\mathrm{Nb}$ increase with increase volatiles, which associated hydrothermal solutions. In addition, no clear relation with highly altered one due to the concentrations of $\mathrm{Zr}$ in most samples with is more than $1 \%$ and not determined by XRF.

\subsubsection{Niobium and Tantalum}

Niobium and tantalum are transition metals with very similar physical chemical properties, and thus are commonly grouping together. The columbite-tantalite group is the most group of tantalum and niobium bearing minerals.

The bulk of $\mathrm{Nb}$ in a magmatic melts exist as $\left(\mathrm{NbO}_{4}\right)^{3-}$ complex, because of high value of ionic potential. The large size of the complexes compared with $\left(\mathrm{SiO}_{4}\right)^{4-}$ will lead to concentration of these ions in residual melts. Also as mentioned above $\mathrm{Nb}$ increases with increasing volatiles in magma.

The preliminary investigation of Nusab El Balgum altered peralkaline granites indicate occurrence ferrocolumbite mineral (Figure 5(a)) and $\mathrm{Nb}$ range from 207 to 512 ppm in slightly altered peralkaline granite but this range varies from 828 to $4427 \mathrm{ppm}$ in highly altered one (Table 1) due to increases of volatiles during post magmatic stage. The plotting $\mathrm{Nb}$ versus $\mathrm{Y}$, eU and eTh (Figures 4(e)-(g)) indicates the strong positive relation with $\mathrm{Y}$ in highly altered peralkaline granite and with no clear relations with slightly, this indicate the role of intensely post magmatic hydrothermal alterations in concentrated these elements.

\subsubsection{Uranium and Thorium}

Uranium and thorium are members of the actinide family, which belongs to group IVA. Uranium occur in two oxidation states $\left(\mathrm{U}^{4+}\right.$ and $\left.\mathrm{U}^{6+}\right)$ but thorium occur in only oxidation state $\left(\mathrm{Th}^{4+}\right) . \mathrm{U}^{4+}$ and $\mathrm{Th}^{4+}$ have similar chemical properties (e.g. ionic charge, effective radius, and coordination number) making substitution of $U$ and Th com- mon under reducing conditions.

The solubility and stability of $\mathrm{U}^{4+}$ in silicate melts of various compositions is controlled by oxygen fugacity. At lower oxygen fugacity the solubility of $\mathrm{U}^{4+}$ in silicate melts become higher [23], and the uranium remain in $\mathrm{U}^{4+}$ state like $\mathrm{Th}^{4+}$, but when the oxygen fugacity increases, in magmatic silicate fluids and therefore the geochemical path of $\mathrm{Th}^{+4}$ and $\mathrm{U}^{4+}$ diverge. In general, during magmatic differentiation $U$ and $T h$ content increase from basaltic to low Ca-granitic rocks. However, low $\mathrm{Ca}$ granites (e.g. alkaline granites) may be enrichment in $\mathrm{Th}$ relative to $U$ because some $U$ enters into an aqueous phase as uranyle ions during the final stages of crystallization of granitic magmas. In surface and highly oxidizing conditions, $\mathrm{U}^{6+}$ is the dominant stable form and thorium occurs as $\mathrm{Th}^{4+}$.

Thorite and uranothorite are main thorium minerals in the study area. Thorite occurs as black to brownish black grains associated with silica and iron oxides in altered granitic rocks of the studied area. Thorite grains are less often massive. Uranothorite usually occurs in the studied rocks as yellowish brown or orange color crystals and usually occur as impregnated grains. Uranothorite crystallize in tetragonal system and usually contains $10 \%$ to $16 \%$ of $\mathrm{UO}_{2}$. Uranothorite in the studied rocks of this the area identified by XRD (Figure 5(a)). The eTh ranges in slightly altered peralkaline granite from 24 to $81 \mathrm{ppm}$ and from 37 to $1107 \mathrm{ppm}$ in highly altered one.

Uranium minerals are occur as secondary pale yellow radiated acicular, shows rose-shape crystals of autunite upon quartz crystals or filling the fractures in crystals of the altered granites as indicated by petrography study (Plates 2(c) and (d)). In addition, most of them occur in amorphous state (Plate 2(b)). The concentration of eU in slightly altered peralkaline granite range from 13 to 30 ppm and from 38 to 298 ppm in highly altered one (Table (1)). Plotting eU versus eTh (Figure 4(h)) show strong positive relation and, in addition that all the analyzed 


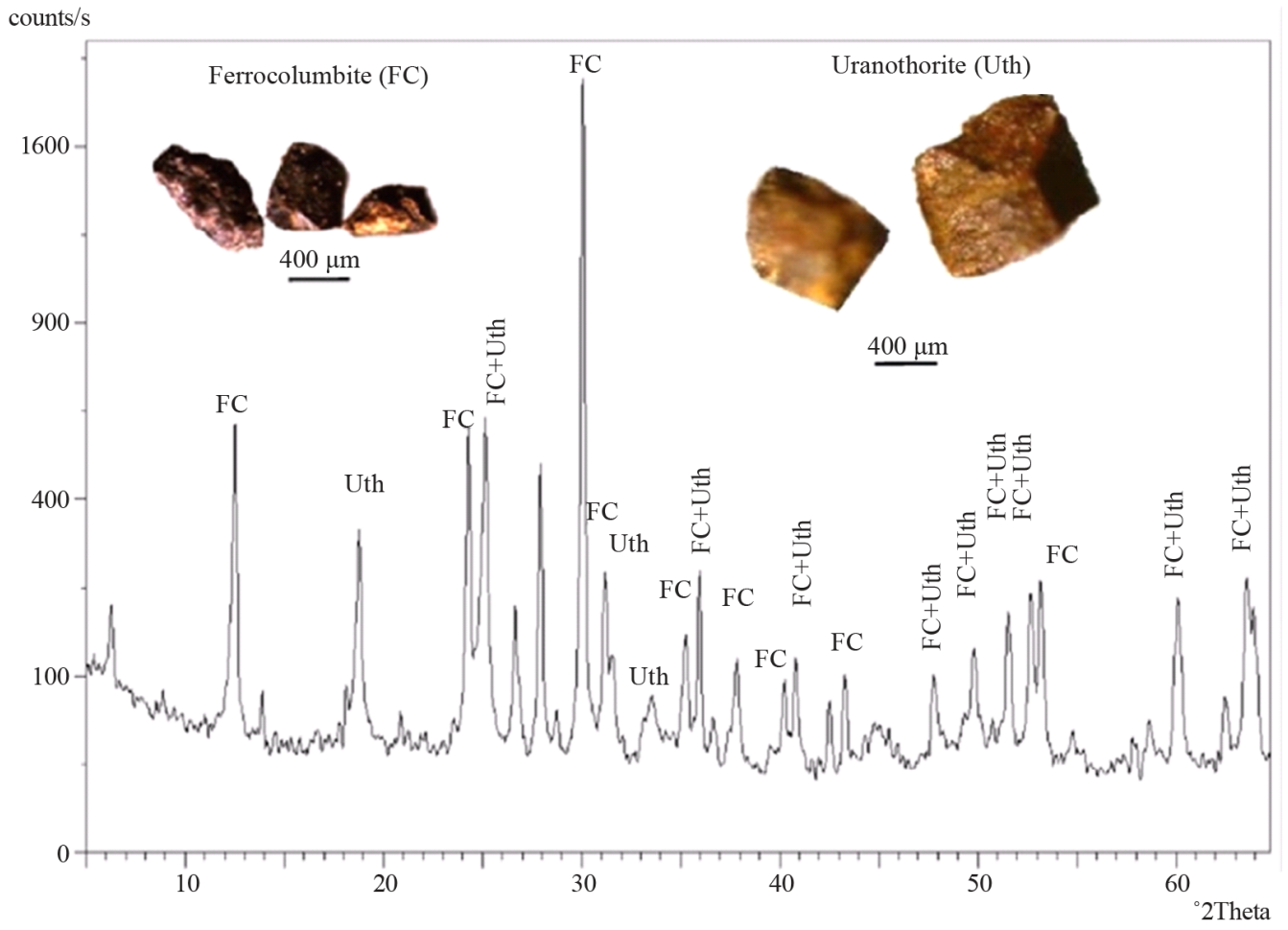

(a)

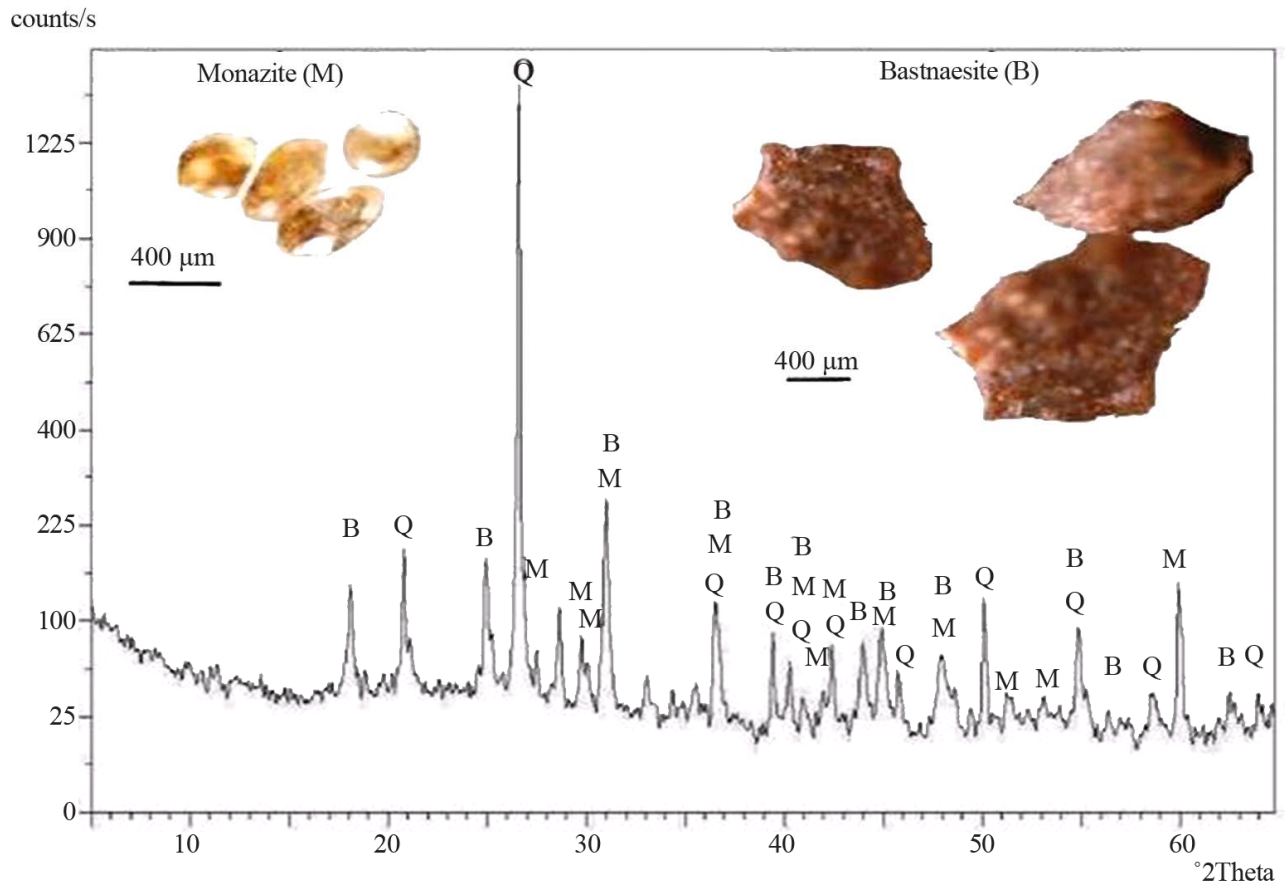

(b)

Figure 5. XRD analysis pattern and photomicrographs for (a) ferrocolumbite (Fc) and uranothorite (Uth) and (b) monazite (M) and bastnaesite (B).

samples located under the line $\mathrm{Th} / \mathrm{U}=$ one [24] indicating uranium enrichment than thorium. Also all the samples of highly altered granite plotted in mineralized field but the slightly altered one shows the samples plotted in mineralized and non mineralized field. The plotting $\mathrm{Y}$ versus eU and eTh (Figures $\mathbf{4 ( j )}$ and (i)) indicates no clear relations with slightly altered granite and clear positive relations with highly altered one as a result of 
hydrothermal processes.

\subsubsection{REEs}

REEs traditionally have been divided into two groups: the light rare earth elements (LREEs) - lanthanum through europium ( $Z=57$ through 63); and the heavy rare earth elements (HREEs) - gadolinium through lutetium $(\mathrm{Z}=$ 64 through 71). Although yttrium is the lightest REE, it is usually grouping with the HREEs to which it is chemically and physically similar. The REEs are lithophile elements (elements enriched in the earth's crust) that invariably occur together naturally because all are trivalent (except for $\mathrm{Ce}^{4+}$ and $\mathrm{Eu}^{2+}$ in some environments) and have similar ionic radii. The similar radii and oxidation states of the REEs allow for liberal substitution of the REEs for each other into various crystal lattices. This substitution accounts for their wide dispersion in the earth's crust and the characteristic multiple occurrences of REEs within a single mineral.

The concentrations and distribution of REEs in natural deposits are dependent on several petrogenetic processes, including enrichment and complexion in late-stage magmatic or hydrothermal fluids, fractionations into mineral phases, oxidation or reduction, and redistribution during weathering.

Most significant natural concentrations of REEs in nature are in, or associated with, alkaline igneous rocks and carbonatites. The REEs mobility is controlled by $\mathrm{pH}$, high water/rock ratios and abundant complex ions $\mathrm{CO}_{3}^{2-}$, $\mathrm{F}, \mathrm{Cl}, \mathrm{PO}_{4}^{2-}$ and $\mathrm{SO}_{4}^{2-}$ [25].

The preliminary investigations REEs distribution at the Nusab El Balgum altered peralkaline granitic rocks, indicate these elements are associated with bastnaesite, monazite (Figure 5(b)) and xenotime minerals. The brief short note on REES bearing minerals (bastnaesite and monazite) as follow:

Bastnaesite $\left(\mathrm{CeCO}_{3}\right)(\mathrm{OH}, \mathrm{F})$ Bastnaesite mineral is Cerium fluoro-carbonate. Cerium is the dominant metal ion, but various rare earth metals substitute for cerium in the formula. So that, bastnaesite mineralogical group can be divided into three minerals: 1) cerium rich (Ce one); 2) lanthanum rich (La one); and 3) yttrium rich (Y one) form. Bastnaesite ranges in color from honey-yellow to reddish brown and crystallized in hexagonal system. It shows vitreous luster from transparent to translucent. Bastnaesite found in carbonate and alkaline igneous intrusive rocks as well as hydrothermal sources in metamorphic zones. This mineral identified by XRD (Figure 5(b)).

Monazite is monoclinic form adopted by light lanthanide or orthophosphate $[26,27]$. The structure of monazite is similar to that of zircon in several important ways. The monazite type structure is stable at either low temperature or intermediate pressure or at low pressure and intermediate temperature [28]. The experimental studies in $\mathrm{AtO}_{4}$ systems $\left(\mathrm{AtO}_{4}=\right.$ compounds that are isostructure with zircon; these are the zircon group minerals) indicate that, for a given temperature, the polymorphic sequence with increasing pressure is zircon $\rightarrow$ monazite $\rightarrow$ scheelite while the polymorphic sequence at fixed pressure and increasing temperature is monazite $\rightarrow$ scheelite $\rightarrow$ zircon. Crystals occur as brown to reddish brown prismatic or tabular habit. These crystals sometimes have negligible amount of $\mathrm{Mg}, \mathrm{Mn}, \mathrm{Pb}, \mathrm{Fe}, \mathrm{Al}$ and $\mathrm{H}_{2} \mathrm{O}$. This mineral is the chief source to Th and REE (especially Ce). Monazite in the study are identified by XRD (Figure 5(b)).

To try understanding of the physo-chemical conditions prevailed during the hydrothermal alterations in Nusab El Balgum peralkaline granitic rocks, the chondritic values given by [18] are used for the REE normalization in the present work. In a chondrite, normalized REEs values diagram, samples $(9 \& 10)$ of altered peralkline granites (Figure (6)) are similar and indicate that:

1) Two samples show higher LREEs enriched pattern $(\mathrm{La} / \mathrm{Gd}=11.34$ and 12.25) means a) the alteration processes took place under open system [29] and b) the peralkaline granite is evolved from magma of lithospheric rifting.

2) Two samples show $-\Delta \mathrm{Ce}<1$ anomaly (Table 2) This means that the alteration fluids were slightly oxic [30].

3) Two samples show strong negative $-\Delta \mathrm{Eu}<1$, (Table 2).

This means the nature of residual peralkaline melt: 1) it was extremely rich in fluorine and $\mathrm{H}_{2} \mathrm{O}$ and thus very low viscosity [31], despite its low temperature $\left(<650^{\circ} \mathrm{C}\right)$; 2 ) it was strong depleted in feldspar-compatible elements, as indicated by strong negative Eu anomalies; and 3) it had abundances of HFSE cations. Redistribution of elements took place by the hydrothermal solutions [32].

\section{Conclusions}

The Nusab El Balgum mass complex can be considered

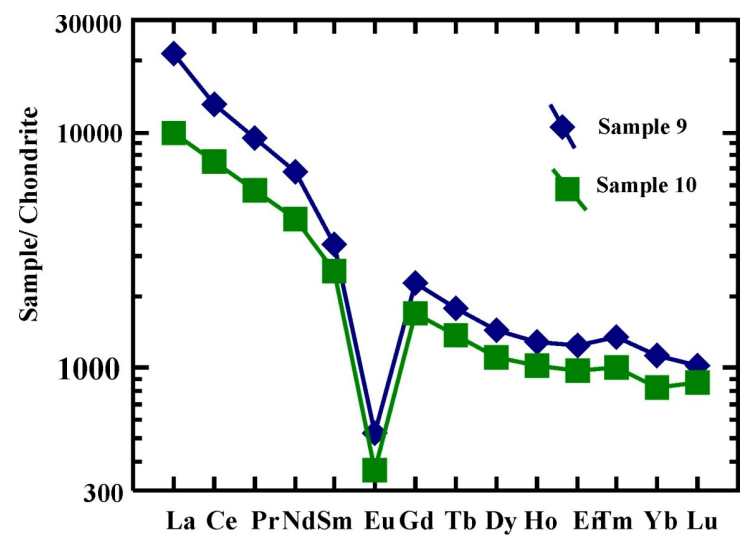

Figure 6. Normalized REE pattern of the altered Nusab El Balgum peralkaline granites. 
or represent a caldera complex, where its diameter greater many times than that of the included vent 3.5 $\mathrm{Km} \times 12 \mathrm{Km}$ ). The crater is composed mainly of rhyolitic lava flow, banded tuffs, agglomerates, breccias of vent type as well as dykes. The rest of Nusab El Balgum area is represented sub-volcanic granitic intrusions (incomplete ring and small stock as well as small dyke) and many volcanic dykes (trachyte, bostonite, rhyolite and porphyritic rhyolite) sub volcanic altered peralkaline granites. The volcanicity of these mass took place during Mesozoic time because of lithospheric weakness of Central African lineament runs ENE-WSW direction (the most important part of this lineament in the southwest of Egypt is the Kalabsha fault [16] intersection with Tarafawi-Qena-South Sinai Arch of NE direction.

The volcanicity started by main mass of the crater, followed by peralkline granites and the final stage of Nusab El Balgum represented by the dykes cut all the rocks of Nusab El Balgum mass. These dykes are different run in directions but the most of them run in NNE-SSE direction. In addition, they differ in width and length.

The peralkaline granites undergo the hydrothermal alterations (e.g. Silicification, Fe-Mn oxy-hydroxides, Sericitization, Carbonatization and Kaolinitization). These granites at south part of the crater (stock-like intrusion) divided according the degree of hydrothermal alterations to slightly altered (occur as roof pendant of fragments) and highly hematized one with extreme enrichments of rare metal such as (such as $\mathrm{Zr}, \mathrm{Nb}, \mathrm{U}$ and $\mathrm{Th}$ and REEs). The highest concentrations (e.g., $>1 \% \mathrm{Zr}, 0.5 \% \mathrm{Nb}, 2.6 \%$ total REEs, Y up to $1 \%$, eU up to $300 \mathrm{ppm}$ and eTh up to $1100 \mathrm{ppm}$ ). The Preliminary mineralogy and petrography studies indicate that the rare metal bearing minerals are thorite and uranothorite autunite, amorphous secondary uranium, zircon, ferrocolumbite while the REEs bearing minerals are bastnaesite, monazite and xenotime. The binary diagrams of $\mathrm{Zr}$ versus $\mathrm{Nb}, \mathrm{Y}$, eU and eTh, $\mathrm{Nb}$ versus $\mathrm{Y}$, eU and eTh, $\mathrm{Y}$ versus eU and eTh indicate extreme enrichment in these elements is associated with intensely hematised peralkaline granite.

To understanding the physo-chemical conditions prevailed during the hydrothermal alterations in Nusab El Balgum peralkaline stock-like intrusion of granite, the chondritic values given by [18] are used for the REE normalization in the present work. In a chondrite, normalized REE values diagram samples ( $9 \& 10)$ of altered peralkline granite are similar and indicate that:

1) The higher LREEs enriched pattern $(\mathrm{La} / \mathrm{Gd}=11.34$ and 12.25) means: 1) the alteration processes took place under open system [29] and 2) the peralkaline granite is evolved from magma of lithospheric rifting.

2) The negative $-\Delta \mathrm{Ce}<1$ anomaly (Table 2). This means that the alteration fluids were slightly oxic [30].

3) The strong negative $-\Delta \mathrm{Eu}<1$, (Table 2). This means the nature of residual peralkaline melt: 1) it was extremely rich in fluorine and $\mathrm{H}_{2} \mathrm{O}$ and thus very low viscosity [31], despite its low temperature $\left.\left(<650^{\circ} \mathrm{C}\right) ; 2\right)$ it was strong depleted in feldspar-compatible elements, as indicated by strong negative Eu anomalies; and 3) it had abundances of HFSE cations. Redistribution of elements took place by the hydrothermal solutions [32].

The HFSE mobile as fluoride complexes in the orthomagmatic fluids and these fluids are alkaline rich in $\mathrm{F}$ and have exceptionally low content of $\mathrm{Ca}$, where mineralogical composition of altered granite are suitable for HFSE transportation. The depositions of these elements in the apical parts of the pluton due to mixed with the minor concentrations of $\mathrm{Ca}$ from meteoric water, which cause precipitation as $\mathrm{CaF}_{2}$ and consequently the depositions of these elements $[8,30]$.

\section{Acknowledgements}

We wish to thanks to Dr. Ata, A. and Dr. Adel, A. and Dr. Nasser, M. for helping us during fieldwork.

\section{REFERENCES}

[1] V. I. Kovalenko, G. M. Tsaryeva, A. V. Goreglyad, V. V. Yarmoluk and V. A. Troitsky, "The Peralkaline-Granite Related Khaldzan-Buregtey Rare Metal (Zr, Nb, REE) Deposit, Western Mongolia," Economic Geology, Vol. 90, No. 3, 1955, pp. 530-547.

doi:10.2113/gsecongeo.90.3.530

[2] Z. Hadj-Kaddor, J. P. Liegeois, D. Demaiffee and R. Caby, "The Alkaline-Peralkaline Granitic Post-Collisional Tin Zebane Dyke Swarm (Pan-African Shield Algeria): Pre Valent Mantle Signature and Late Agpaitic Differentiation," Lithos, Vol. 45, No. 1-4, 1998, pp. 223-243. doi:10.1016/S0024-4937(98)00033-4

[3] S. Salvi and A. E. Williams-Jones, "Alteration HFSE Mineralization and Hydrocarbon Formation in Peralkaline Igneous System Insight from the Lake Strange Pluton, Canada," Lithos, Vol. 91, No. 1-4, 2006, pp. 19-34. doi:10.1016/j.lithos.2006.03.040

[4] C. Peiffert, C. Nguyen-Trung and M. Cuney, "Uranium in Granitic Magmas: Part 2 Experimental Determination of Uranium Solubility and Fluid-Milt Partition Coefficient in the Uranium Oxides-Haplogranite- $\mathrm{H}_{2} \mathrm{O}-\mathrm{NaX}(\mathrm{X}=\mathrm{Cl}, \mathrm{F})$ system at $770^{\circ} \mathrm{C}, 2 \mathrm{Kbar}, "$ Geochimica et Comsmochimica Acta, Vol. 60, 1966, pp. 659-662.

[5] R. I. Linen and H. Keppler, "Columbite Solubility in Granite Melts Consequences for the Enrichment and Fractionation of $\mathrm{Nb}$ and $\mathrm{Ta}$ in the Earths Crust: Contribution to Mineralogy and Petrography," Vol. 128, No. 2-3, 1997, pp. 213-227. doi:10.1007/s004100050304

[6] C. M. Scarf, "Viscosity of Apantellerite Melts at One Atmosphere," Canadian Mineralogist, Vol. 60, 1977, pp. 185-189.

[7] D. L. Trueman, J. C. Pedersen, L. de St Jorre and D. G. W. Smith, "The Thor Lake Rare-Metal Deposits. North- 
west Territories," In: R. P. Taylor and D. F. Strong, Eds., Recent Advances in the Geology of Granite-Related Mineral Deposits, Canadian Institute of Mining and Metallurgy, Montreal, 1988, pp. 280-290.

[8] S. Salvi and A. E. Williams-Jones, "The Role of Hydrothermal Processes in Concentrating High-Field Strength Elements in the Lake Strange Peralkaline Complex, Northeastern Canada," Geochimica et Comsmochimica Acta, Vol. 60, No. 11, 1996, pp. 1917-1932. doi:10.1016/0016-7037(96)00071-3

[9] P. De Gruyter and T. A. Vogel, "A Model for the Origin of the Alkaline Complexes of Egypt," Nature, Vol. 291, No. 5816, 1981, pp. 571-574. doi:10.1038/291571a0

[10] M. Y. Meneisy and M. Y. Volcanicity, In: R. Said, Ed., The Geology of Egypt, A. A. Balkema, Rotterdam, 1990, pp. 157-174.

[11] M. S. Garson and M. Krs, "Geophysical and Geological Evidence of the Relationship of Red Sea Transverse Tectonics to Ancient Fractures," Geological Society of America Bulletin, Vol. 87, No. 2, 1976, pp. 169-181. doi:10.1130/0016-7606(1976)87<169:GAGEOT>2.0.CO; $\underline{2}$

[12] R. Black, J. Lameyer and B. Bonin, "The Structural Setting of Alkaline Complexes," Journal of African Earth Sciences, Vol. 3, No. 1-2, 1985, pp. 5-16.

[13] P. Bowden, "The Geochemistry and Mineralization of Alkaline Ring Complexes in Africa (A Review)," Journal of African Earth Sciences, Vol. 3, No. 1-2, 1983, pp. 1739.

[14] N. L. El Agami and H. M. Abdalla, "Geochemistry of Garra El Hamra Y, Th, REE-Mineralized Peralkaline Granite-Syenite Complex, Southwestern Desert, Egypt. A Metallogenetic Constraint. Egypt," Min., Vol. 15, 2006, pp. 43-77.

[15] L. T. D. Conoco-Corporation, "Geological Map of South Western Desert Egypt, 1987, Scale 1:500.000,” Sheet No. NF 53 NV, Gilf Kabeir Plateau, Egyptian General Petroleum Corporation, Cairo, 1987.

[16] M. E. Issawi, "The Geology of Kurkur Dungul Area," Egyptian Geological Survey, Paper No. 46, 1968, 102 pp.

[17] H. Schandelmeier, A. Rich and G. Franz, "Outline of the Geology of Magmatic Units between Gabal Uweinat and Bir Safsaf (SW Egypt/NW Sudan)," Journal of African Earth Sciences, Vol. 1, No. 3-4, 1983, pp. 275-283.

[18] S. R. Taylor and S. M. McClennan, "The Continental Crust: Its Composition and Evolution," Blackwell Scientific Publications, Oxford, 1985.

[19] P. Bowden, "Zirconium in Younger Granites of Northern Nigeria. Geochimica et Comsmochimica Acta, Vol. 30, No. 10, 1966, pp. 985-993. doi:10.1016/0016-7037(66)90113-X

[20] E. C. T. Chao and M. Fleischer, "Abundace of Zirconium in Igneous Rocks," 21st International Geological Congress, Norden, Part 1, 1960, pp. 106-131.
[21] S. R. Taylor, "The Application of Trace Elements Data to Problems in Petrology, Physics and Chemistry of the earth," Pergamon Press, Oxford, 1965, pp. 1-133.

[22] A. E. Ringwood, "The Principles Governing Trace Element Behaviour during Magmatic Crystallization. Part II: The Role of Volcanic Rocks," Geochimica et Comsmochimica Acta, Vol. 7, 1955, pp. 242-254. doi:10.1016/0016-7037(55)90036-3

[23] G. Calas, "Etude Experimental due Comportement del' Uranium dans les Magmas. Etats d'Oxydation et Coordinance," Geochimica et Comsmochimica Acta, Vol. 43, No. 9, pp. 1521-1531.

[24] K. J. Wenrich, "Mineralization of Breccia Pipes in Northern Arizona (abs.)," In: N. A. Bogdanov, Ed., Special Session of the International Lithosphere Programme: 27th International Geological Congress, 1984, pp. 380381.

[25] J. R. Haas, E. L. Shock and D. C. Sassani, "Rare Earth Elements in Hydrothermal Systems: Estimates of Standard Partial Molal Thermodynamic Properties of Aqueous Complexes of the Rate Earth Elements at High Pressures and Temperatures," Geochimica et Comsmochimica Acta, Vol. 59, No. 21, 1995, pp. 4329-4350. doi:10.1016/0016-7037(95)00314-P

[26] Y. Ni, J. M. Hughes and A. N. Mariano, "Crystal Chemistry of the Monazite and Xenotime Structures," American Mineralogist, Vol. 80, 1995, pp. 21-26.

[27] L. A. "Boatner Synthesis, Structure and Properties of Monazite, Pretulite and Xenotime," Reviews in Mineralogy and Geochemistry, Vol. 48, No. 1, 2002, pp. 87-121. doi:10.2138/rmg.2002.48.4

[28] V. S. Stubican and R. Roy, High-Pressure ScheeliteStructure Polymorphs of Rare Earth Vanadates and Arsenate," Zeitschrift für Kristallographie, Vol. 119, No. 1-2, 1963, pp. 90-97. doi:10.1524/zkri.1963.119.1-2.90

[29] W. Irber, "The Lanthanide Tetrad Effect and Its Correlation with $\mathrm{K} / \mathrm{Rb}, \mathrm{Eu} / \mathrm{Eu}^{*}, \mathrm{Sr} / \mathrm{Eu}, \mathrm{Y} / \mathrm{Ho}$ and $\mathrm{Zr} / \mathrm{Hf}$ of Evolving Peraluminous Granite Suites," Geochimica et Comsmochimica Acta, Vol. 63, No. 3-4, 1999, pp. 489-508. doi:10.1524/zkri.1963.119.1-2.90

[30] S. A. Elatta, "Occurrence of Rare Metals at Gabal Abu Khruq Area, South Eastern Desert, Egypt," Ph.D. Thesis, Faculty of Science, Ain Shams University, Cairo, 2007, $74 \mathrm{pp}$.

[31] D. R. Baker and J. Vaillancourt, "The Low Viscosities of $\mathrm{F}+\mathrm{H}_{2} \mathrm{O}$-Bearing Granitic Melts and Implications for Melt Extraction and Transport," Earth and Planetary Science Letters, Vol. 132, No. 1, 1995, pp. 199-211.

[32] M. Bau and P. Dulski, "Comparing Yttrium and Rare Earths in Hydrothermal Fluids from the Mid-Atlantic Ridge: Implications for $\mathrm{Y}$ and REE Behaviour during Near-Vent Mixing and for the Y/Ho Ratio of Proterozoic Sea Water," Chemical Geology, Vol. 155, No. 1-2, 1999, pp. 77-90. doi:10.1016/S0009-2541(98)00142-9 